\title{
Utilization of bacterial consortium for oil sludge biodegradation using bioslurry method
}

\author{
Ni'matuzahroh'1, Muslikhah'1, Nur Indradewi Oktavitri' ${ }^{1}$, Nastiti Trikurniadewi' ${ }^{1}$, Fatimah', Sri Sumarsih² and Hanif \\ Yuliani $^{3}$
}

\begin{abstract}
${ }^{1}$ Department of Biology, Faculty of Science and Technology, Universitas Airlangga 60115 Surabaya, Indonesia.
${ }^{2}$ Department of Chemistry, Faculty of Science and Technology, Universitas Airlangga 60115 Surabaya, Indonesia.

${ }^{3}$ Agency for the Assessment and Application of Technology, BPPT, 15314 South Tangerang, Indonesia. Email: nimatuzahroh@fst.unair.ac.id
\end{abstract}

\begin{abstract}
Aims: Oil sludge is one of pollutant sources in the environment. Bacterial abundance, interaction, and compatibility of environmental factors ensure the success of biodegradation. The purpose of this study was to determine the effectiveness of bacterial consortium in degrading oil sludge using bioslurry method.

Methodology and results: The research design used was completely randomized design $4 \times 5$ with variation of bacterial consortium concentration and incubation time. Composition of contaminant and liquid phase in bioslurry method was $1: 9$ ratio with aeration, at room temperature. The liquid phase comprises distilled water with the addition of $2 \%(\mathrm{v} / \mathrm{v})$ of molasses as nutrient for bacterial growth. Bacterial growth was evaluated using the Total Plate Count (TPC) method. Total Petroleum Hydrocarbon (TPH) measurements were evaluated using the gravimetric method while the oil sludge hydrocarbon component was evaluated by Gas Chromatography Mass Spectrophotometry (GCMS). The pH and temperature data were analyzed descriptively while TPC and TPH data were analyzed using Two Way ANOVA ( $\alpha=0.05$ ). The bacterial consortium could grow on oil sludge hydrocarbon substrate with a range of temperature of $29^{\circ} \mathrm{C}-32^{\circ} \mathrm{C}$ and an optimum $\mathrm{pH}$ of 7 . Biodegradation of $\mathrm{TPH}$ was $70.48 \%$ at consortium concentration of $15 \%$ in 14 days of incubation.
\end{abstract}

Conclusion, significance and impact of study: Biodegradation of oil sludge using a bacterial consortium by bioslurry method is one of the effective methods to reduce pollutants in the management of oil sludge.

Keywords: Bacterial consortium, biodegradation, bioslurry, molasses, oil sludge

\section{INTRODUCTION}

The amount of waste in the oil industry increases with the increase of oil industry activity. One of the industrial wastes is the oil sludge that settles at the bottom of the crude oil storage tanks. Periodically, the oil tank must be cleaned to accommodate new oils. Furthermore, the oil sludge at the base of the oil tanks becomes a potentially polluting material to the environment. The oil sludge contains the main compounds of aliphatic and aromatic hydrocarbons such as benzene, toluene, ethylbenzene and xylene (BTEX), polycyclic aromatic hydrocarbons (PAHs), and heavy metal elements. Oil sludge is toxic, carcinogenic and mutagenic (Kriipsalu et al., 2008; Liu et al., 2012). Environmental contamination by the ingredients of the oil sludge can have an effect on the living organisms around it (Sari et al., 2018). In addition, the exploited sludge in the environment can reach the groundwater, lakes or water sources that are the main source of clean water supply for both domestic and industrial needs (Atlas and Bartha, 1998).
Oil sludge hydrocarbon pollution treatments have been widely done physically, chemically, and biologically. Biodegradation is one of the most cost effective and cheaper ways than physical and chemical methods (Mansur et al., 2015). Biodegradation of hydrocarbons utilizes the role of potential microbes in decomposing hydrocarbons. Previous study has revealed the ability of Acinetobacter sp. P2, Bacillus subtilis 3KP, (1), Micrococcus sp. LII 61, and Pseudomonas putida TI (8) in oil removal and degradation of hydrocarbons in molasses substrates. The oil removal was supported by biosurfactant products which produced in molasses substrate (Ni'matuzahroh et al., 2016a). Microbes can break down harmful compounds into harmless compounds by releasing their enzymes (Karigar and Rao, 2011). Oxygenase enzymes were produced by these aerobe hydrocarbonoclastic isolates on medium with aliphatic and polyaromatic hydrocarbon inductions (Sumarsih et al., 2017). 
Efforts are being made to accelerate the biodegradation of hydrocarbons by maintaining microbial survival, increasing microbial populations, and facilitating contact between contaminants and microbes through its biosurfactant product. Mix bacterial culture can increase biodegradation rate compared to pure culture (Cerqueira et al., 2011). According to Leahy and Colwell (1990), single microbial species can only degrade certain compounds in the oil component, while using a microbial consortium can degrade hydrocarbon compounds that cannot be degraded by a single species because of the resulting enzyme capacity. Limitations of oxygen are one of the important factors that inhibit the biodegradation of hydrocarbons by aerobe hydrocarbonoclastic bacteria.

Bioslurry technology in biodegradation is effectively used to degrade hazardous contaminants present in sediments, solids or sludges in a reactor equipped with an agitator and aerator to supply oxygen during biodegradation (United States Environmental Protection Agency or USEPA, 1990). According to Gonzalez et al. (2008), the advantages possessed by bioslurry reactors in the biodegradation of contaminants include increasing mass transfer rate and contact between microorganisms, nutrients and pollutants. USEPA (2009) stated that the addition of microbes and aeration in the bioslurry reactor can be done to improve the performance of the reactor to the degradation of industrial waste. Sufficiency of macro and micro elements is needed to support microbial growth that has the potential to degrade hydrocarbons.

The incorporation of the biostimulation and bioaugmentation methods in the bioslurry reactor will optimize the biodegradation process of hydrocarbons in the oil sludge (Ni'matuzahroh et al., 2016b). Utilization of molasses as biostimulation agents in the biodegradation of oil hydrocarbons began to receive attention (Ni'matuzahroh et al., 2017). This study reported the influence of concentration variation of bacterial consortium on molasses medium and variation of incubation time on effectiveness of biodegradation of oil sludge using bioslurry method.

\section{MATERIALS AND METHODS}

\section{Research sites}

The research was conducted in an Ecology Laboratory, Environmental Laboratory and Microbiology Laboratory of Faculty of Science and Technology, Universitas Airlangga, Indonesia.

\section{Material}

Oil sludge came from Pertamina Balongan, Indonesia, in the form of liquid sludge simulated with the addition of sterile sand from Mojokerto, Indonesia, that has been sieved with mesh 200 with a composition of $30 \%(\mathrm{v} / \mathrm{w})$. The bacterial consortium consists of four hydrocarbonoclastic bacteria, such as Acinetobacter sp. P2 (1), B. subtilis 3KP, Microccocus sp. LII 61, and P. putida TI (8), which are collection cultures of Microbiology
Laboratory of Universitas Airlangga. The solvent used to extract hydrocarbons from the oil sludge was $n$-hexane. Media for culturing bacterial isolates include Nutrient Agar (NA) and Nutrient Broth (NB). Molasses was used as nutrients for bacterial growth.

\section{Preparation for bioslurry reactor}

Bioslurry reactors were used with glass and equipped with an aerator. The reactor has a capacity of $1.5 \mathrm{~L}$, cylindrical, with a diameter of $0.1 \mathrm{~m}$, and a height of 0.15 $\mathrm{m}$ (freeboard $0.02 \mathrm{~m}$ ). The design of the reactor is illustrated in Figure 1.

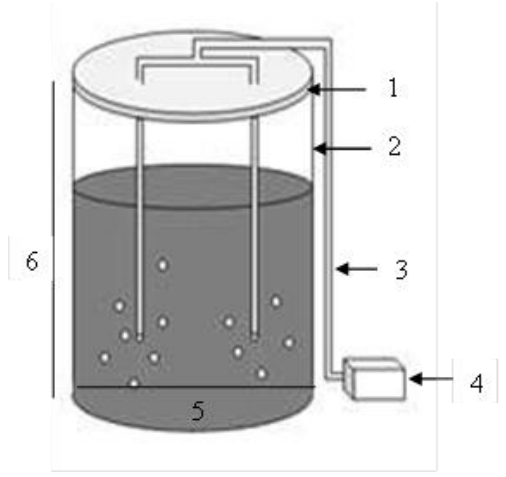

Figure 1: Bioslurry reactor design.

Information of Figure1:

1. Freeboard

2. Cylindrical glass

3. Pipe

4. Aerator

5. Diameter of reactor

6. Height of reactor

\section{Preparation of bacterial isolate consortium}

Each bacterial isolate was streaked on a slant NA medium, and then incubated for $24 \mathrm{~h}$ at $25^{\circ} \mathrm{C}$. The growing isolates were inoculated on NB medium and incubated for $24 \mathrm{~h}$ on the rotary shaker at $25^{\circ} \mathrm{C}$. Each culture was adjusted to optical density $(\lambda 600 \mathrm{~nm})$ up to 0.5 . Consortium was composed with the same proportion of each bacterial culture and was applied in each bioslurry reactor.

\section{Research design}

This was a laboratory experimental study using a completely randomized design of $5 \times 4$ factorial pattern with three replications. This research consists of two factors, namely variation of concentration of microbial consortium and length of incubation time. The consortium concentration of microbes added consisted of $0 \%$ (control), 5\%, 10\% and $15 \%(\mathrm{v} / \mathrm{v})$, while the incubation time was $0,3,7,10$ and 14 days. The study design is presented in Table 1. 
Malays. J. Microbiol. Vol 15(4) Special Issue 2019, pp. 327-332 DOI: http://dx.doi.org/10.21161/mjm.191549

Table 1: Treatment variation of microbial consortium concentration and incubation time.

\begin{tabular}{ccccc}
\hline \multirow{2}{*}{$\begin{array}{c}\text { Incubation time } \\
\text { (Days) }\end{array}$} & \multicolumn{3}{c}{$\begin{array}{c}\text { Concentration of bacterial } \\
\text { Consortium }(\% \text { v/v) }\end{array}$} \\
\cline { 2 - 5 } & V0 & V1 & V2 & V3 \\
\hline H0 & H0V0 & H0V1 & H0V2 & H0V3 \\
H1 & H1V0 & H1V1 & H1V2 & H1V3 \\
H2 & H2V0 & H2V1 & H2V2 & H2V3 \\
H3 & H3V0 & H3V1 & H3V2 & H3V3 \\
H4 & H4V0 & H4V1 & H4V2 & H4V3
\end{tabular}

Note: V0: Concentration of microbial consortium $0 \%(\mathrm{v} / \mathrm{v})$ as a control of treatments, $\mathrm{V} 1$ : Concentration of microbial consortium $5 \%(\mathrm{v} / \mathrm{v})$, V2: Concentration of microbial consortium 10\% (v/ v), V3: Concentration of microbial consortium 15\% (v/v), H0: Day 0, H1: Day 3, H2: Day 7, H3: Day 10 and H4: Day 14

\section{Biodegradation test}

The biodegradation test was performed by comparison between the contaminant and the liquid phase in the bioslurry treatment of 1:9. The bioslurry reactor was filled with $100 \mathrm{~g}$ of oil sludge, with consortium concentration at each reactor was $0 \%, 5 \%, 10 \%$ and $15 \%(\mathrm{v} / \mathrm{v})$, and poured into it the distillated water with $2 \%$ molasses $(\mathrm{v} / \mathrm{v})$ up to the total volume of $1 \mathrm{~L}$ aseptically.

\section{Determination of Total Petroleum Hydrocarbon (TPH) and percentage of biodegradation}

The remaining TPH concentration during the treatment was measured by the modified gravimetric method of USEPA (1994) and Panda et al. (2013). The extraction was performed by sampling, $30 \mathrm{~mL}$ culture of each reactor at a predetermined observation point using $n$ hexane at a ratio of $1: 1$. The soluble hydrocarbons in $n$ hexane were evaporated to separate the hydrocarbon phase with the solvent. The extraction was done at a temperature of $60{ }^{\circ} \mathrm{C}$. The hydrocarbons residues were weighed to obtain the weight of the remaining total petroleum hydrocarbons (TPH). Then, TPH was analyzed using GC-MS to identify content of the remaining hydrocarbon compounds. The value of TPH was used to determine the percentage of biodegradation using formula as below:

eHydrocarbon biodegradation $(\%)=$ (Initial TPH - final TPH) / (Initial TPH) × 100\%

\section{Viability analysis of bacterial consortium}

Counting the number of bacterial cells was performed at each observation of incubation time using pour plate method with a certain dilution series. Nutrient Agar (NA) medium was used to grow bacterial isolates that play a role in hydrocarbon biodegradation. Incubation was carried out for $24 \mathrm{~h}$ at $25^{\circ} \mathrm{C}$. TPC results were displayed with $\mathrm{CFU} / \mathrm{mL}$ log values. At each point, measurements of temperature and $\mathrm{pH}$ were also made.

\section{Data analysis}

Bacterial growth was evaluated using the Total Plate Count (TPC) method. TPH measurements were conducted by the gravimetric method, evaluated by Gas Chromatography Mass Spectrophotometry (GCMS). The $\mathrm{pH}$ and temperature data were analyzed descriptively, while TPC and TPH data were analyzed using Two Ways ANOVA $(\alpha=0.05)$ and continued with Duncan test.

\section{RESULTS AND DISCUSSION}

The success of oil sludge hydrocarbon biodegradation is indicated by parameters such as increasing of microbial number $(\mathrm{CFU} / \mathrm{mL})$; reduction of total residual weight of Petroleum Hydrocarbon $(\mathrm{g} / \mathrm{g})$ on slurry substrate; intermediate metabolite compound formation; $\mathrm{pH}$ and temperature change during treatment.

Table 2: Combination of consortium concentration and length of incubation time to total bacterial number (CFU/mL) and weight loss of oil sludge residue $(\mathrm{g} / \mathrm{g})$.

\begin{tabular}{ccc}
\hline Treatments & $\begin{array}{c}\text { Average of number of } \\
\text { bacteria }(\mathrm{log} \mathrm{CFU} / \mathrm{mL})\end{array}$ & $\begin{array}{c}\text { Average of oil } \\
\text { sludge residue }(\mathrm{g} / \mathrm{g})\end{array}$ \\
\hline H0V0 & $16.549 \pm 0.52^{\mathrm{abcde}}$ & $0.460 \pm 0.009^{\mathrm{k}}$ \\
H1V0 & $15.437 \pm 0.43^{\mathrm{a}}$ & $0.456 \pm 0.019^{\mathrm{k}}$ \\
H2V0 & $17.000 \pm 0.00^{\mathrm{bcdef}}$ & $0.458 \pm 0.001^{\mathrm{k}}$ \\
H3V0 & $17.765 \pm 0.18^{\text {fg }}$ & $0.462 \pm 0.018^{\mathrm{k}}$ \\
H4V0 & $17.537 \pm 1.07^{\text {efg }}$ & $0.431 \pm 0.001^{\mathrm{i}}$ \\
H0V1 & $15.945 \pm 0.61^{\mathrm{ab}}$ & $0.388 \pm 0.004^{\mathrm{i}}$ \\
H1V1 & $16.049 \pm 0.22^{\mathrm{ab}}$ & $0.373 \pm 0.004^{\mathrm{h}}$ \\
H2V1 & $17.347 \pm 0.306^{\text {defg }}$ & $0.359 \pm 0.012^{\mathrm{hi}}$ \\
H3V1 & $18.191 \pm 0.19^{\mathrm{g}}$ & $0.385 \pm 0.040^{\mathrm{i}}$ \\
H4V1 & $19.759 \pm 0.6^{\mathrm{h}}$ & $0.323 \pm 0.004^{\mathrm{h}}$ \\
H0V2 & $15.874 \pm 0.98^{\mathrm{ab}}$ & $0.246 \pm 0.007^{\mathrm{e}}$ \\
H1V2 & $16.199 \pm 0.23^{\mathrm{abc}}$ & $0.198 \pm 0.007^{\mathrm{bc}}$ \\
H2V2 & $17.347 \pm 0.32^{\text {defg }}$ & $0.375 \pm 0.010^{\mathrm{i}}$ \\
H3V2 & $19.7518 \pm 0.63^{\mathrm{h}}$ & $0.269 \pm 0.006^{\mathrm{f}}$ \\
H4V2 & $19.422 \pm 0.037^{\mathrm{h}}$ & $0.235 \pm 0.008^{\mathrm{f}}$ \\
H0V3 & $16.339 \pm 0.66^{\mathrm{abcd}}$ & $0.179 \pm 0.009^{\mathrm{b}}$ \\
H1V3 & $17.212 \pm 0.46^{\text {cdefg }}$ & $0.322 \pm 0.016^{\mathrm{g}}$ \\
H2V3 & $18.293 \pm 1.21^{\mathrm{g}}$ & $0.213 \pm 0.009^{\mathrm{cd}}$ \\
H3V3 & $19.531 \pm 0.14^{\mathrm{h}}$ & $0.186 \pm 0.010^{\mathrm{b}}$ \\
H4V3 & $21.773 \pm 1.22^{\mathrm{i}}$ & $0.142 \pm 0.005^{\mathrm{a}}$ \\
\hline
\end{tabular}

Noted: Data labelled with different letters are statistically different $(\alpha=0.05$; Duncan's test)

The result of combinations of consortium concentration variations and incubation time on total microbial count $(\mathrm{CFU} / \mathrm{mL})$ and weight loss of oil sludge residue $(\mathrm{g} / \mathrm{g})$ are presented in Table 2, while the percentage of biodegradation, $\mathrm{pH}$, temperature measurement and the content of the hydrocarbon compounds resulting from biodegradation are shown in Figures 2, 3, 4 and 5.

Based on Table 2 (Duncan test results), the highest mean log of total microbial number (CFU/mL) in $\mathrm{H} 4 \mathrm{~V} 3$ treatment $(15 \%$ bacterial consortium concentration at 14 days incubation time) was $21.7 \pm 1.22 \mathrm{CFU} / \mathrm{mL}$. It can be 
Malays. J. Microbiol. Vol 15(4) Special Issue 2019, pp. 327-332 DOI: http://dx.doi.org/10.21161/mjm.191549

seen that the residual oil sludge $(\mathrm{g} / \mathrm{g})$ decreases during incubation time. The average weight loss of the highest sludge $(\mathrm{g} / \mathrm{g})$ residue lies in the $\mathrm{H} 4 \mathrm{~V} 3$ treatment of $0.142 \pm 0.0045 \quad(\mathrm{~g} / \mathrm{g})$. The highest percentage of degradation was $70.48 \%$ with oil sludge concentration of $30 \%(0.48 \mathrm{~g} / \mathrm{g})$ for 14 days (Figure 2). Weight loss of oil sludge residue occurred significantly on $\mathrm{H} 4 \mathrm{~V} 3$ treatment (15\% of increase in concentration in 14 days of incubation time). Increasing the number of bacteria and decreasing TPH are the result of metabolic activity of the microbial consortium present in the culture. Indigenous and exogenous bacteria used hydrocarbons in the oil sludge as a carbon source proven by the decreasing value of $\mathrm{TPH}$ in oil sludge. The consortium of exogenous bacteria also has a positive interaction with indigenous bacteria. The increasing number of microbial populations will increase the rate of degradation of hydrocarbon compounds (Wang et al., 2011). With this bioslurry method, the percentage of TPH biodegradation up to $100 \%$ is predicted to be achieved at $48,26,22$ and 18 days of incubation in control treatment and variation of bacterial consortium addition with concentration of $5 \%$, $10 \%$, and $15 \%$ respectively. The calculation analysis using the regression equation is not reported in this paper.

Molasses used as biostimulant agent in the oil sludge biodegradation contain simple sugars and minerals that are required for the growth of consortium-forming bacteria. The previous study also proved that molasses can be used as biosurfactant production media by exogenous bacterial consortium and indigenous bacteria from oil sludge (Ni'matuzahroh et al., 2015; Ni'matuzahroh et al., 2016a; Ni'matuzahroh et al., 2017). Biosurfactant can increase the solubilization of hydrocarbon to enhance the bioavailability of hydrocarbon for hydrocarbonoclastic bacteria. Treatment with biostimulant using molasses was proven to achieve TPH biodegradation up to $33.01 \%$ in 14 days of incubation. The addition of a bacterial consortium 5,10 , and $15 \%$ significantly gave a difference in the percentage of TPH biodegradation compared to controls, which was $55.53 \%, 61.25 \%$ and $70.48 \%$ respectively. The effectiveness of bioaugmentation is influenced by the concentration of bacterial consortium and the interaction between bacteria. Utilization of bacterial consortium more than $15 \%$ is assumed to increase the percentage of hydrocarbon degradation, if the environmental conditions still support the bacterial growth.

The main constraint of the biodegradation process in closed systems is the limitations of oxygen used by aerobic bacteria degrading hydrocarbons. Increased incubation times generally have a growth inhibitory effect indicated by a slowing growth phase (Ni'matuzahroh et al., 2016b). This study has successfully demonstrated that aerated supplying through bioslurry method can ensure the oxygen demand for aerobic microbes to break down hydrocarbons. This is evidenced by the ongoing exponential phase of bacteria at increasing incubation time in all treatments.

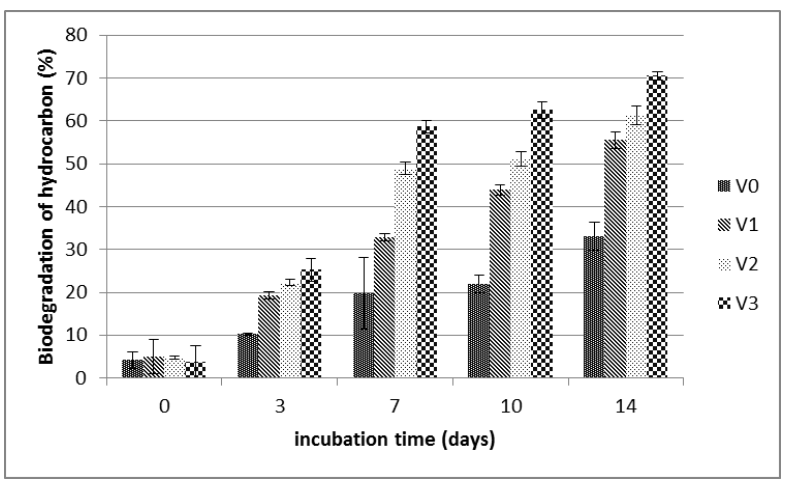

Figure 2: The percentage of hydrocarbon biodegradation at various concentrations of bacterial consortium and time of incubation. V0 is concentration of bacterial consortium $0 \%(\mathrm{v} / \mathrm{v})$ as a control of treatments, $\mathrm{V} 1$ is concentration of bacterial consortium of $5 \%(\mathrm{v} / \mathrm{v}), \mathrm{V} 2$ is concentration of bacterial consortium of $10 \%(\mathrm{v} / \mathrm{v})$, and V3 is concentration of bacterial of consortium $15 \%(\mathrm{v} / \mathrm{v})$.

The complexity of the compounds contained in the oil sludge and the high residual weight are thought to be the causes of the difficulty of the microbes used in the study to degrade the recalcitrant compounds. This can be seen in the increase in the average value of log results in the total number of microbes $(\mathrm{CFU} / \mathrm{mL})$ that are not so high. The substrate attached to the bottom of the bioslurry reactor and adhering to the sand soil during the study was also suspected to be the cause of lack of availability of hydrocarbon sources for the microbial consortium used. The statement is supported by Goswami and Singh (1990) which states that the physical and chemical properties of hydrocarbon such as form, structure, solubility and hydrocarbon toxicity become one of the determinants of accessibility of hydrocarbon compounds by microbes and may affect the use of substrate for bacterial growth.

Based on Figure 3, the $\mathrm{pH}$ value at various treatment variations increased and decreased within the time range of day 0 to day-14. According to Zhu et al. (2001) the biodegradation process will take place optimally if it occurs in sufficient conditions of nutrients, oxygen and $\mathrm{pH}$ ranges from 6-9. Charlena et al. (2010) states that the increasing activity of microbes in the biodegradation of hydrocarbons, will also increase the organic acids produced. Temperature is an environmental factor that affects the biodegradation of hydrocarbons especially on metabolic processes and growth of microorganisms (Silvia, 2010).

Based on Figure 4, it can be seen that the temperature on days 0 and 3 on various concentrations of microbial consortium tends to remain unchanged, but on the 7th, 10th and 14th days it tends to increase. The increase in temperature is likely due to an increase in ambient temperature. Biodegradation of petroleum takes place over a wide temperature range but is not always a major factor limiting biodegradation if other environmental factors exist under optimal conditions (Atlas, 1981). 


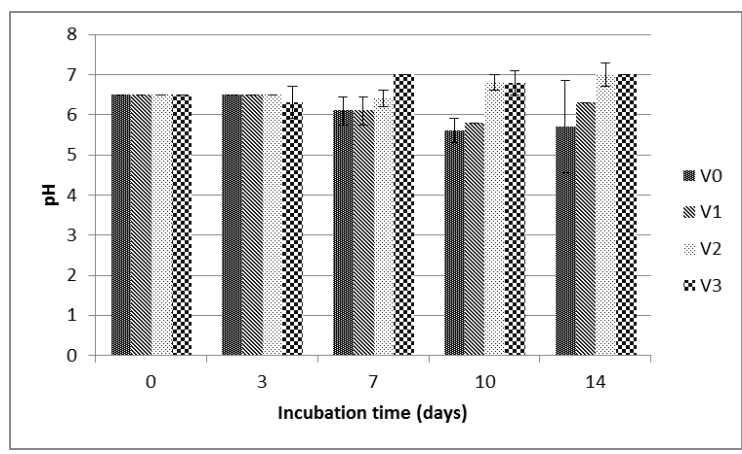

Figure 3: $\mathrm{pH}$ in all treatments in bioslurry reactor. $\mathrm{V} 0$ is concentration of bacterial consortium of $0 \%(\mathrm{v} / \mathrm{v})$ served as a control of treatments, $\mathrm{V} 1$ is concentration of bacterial consortium of $5 \%(\mathrm{v} / \mathrm{v}), \mathrm{V} 2$ is concentration of bacterial consortium of $10 \%(\mathrm{v} / \mathrm{v})$, and $\mathrm{V} 3$ is concentration of bacterial consortium of $15 \%(\mathrm{v} / \mathrm{v})$.

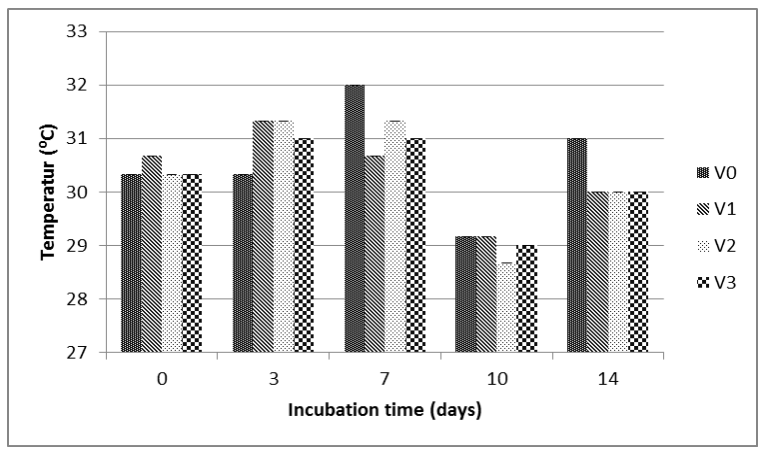

Figure 4: Temperature in all treatments in bioslurry reactor. $\mathrm{V} 0$ is concentration of bacterial consortium of $0 \%$ $(\mathrm{v} / \mathrm{v})$ served as a control of treatments, $\mathrm{V} 1$ is concentration of bacterial consortium of $5 \%(\mathrm{v} / \mathrm{v}), \mathrm{V} 2$ is concentration of bacterial consortium of $10 \%(\mathrm{v} / \mathrm{v})$, and $\mathrm{V} 3$ is concentration of bacterial consortium of $15 \%(\mathrm{v} / \mathrm{v})$.

Overall concentration of microbial consortium, incubation time and other factors such as $\mathrm{pH}$ and ambient temperature will affect the total microbial count and percentage of oil sludge degradation. In the combination treatment, it was found that the best treatment was found in H4V3 (15\% of inoculum with 14 days incubation).

The result of GCMS analysis showed that variation of bacterial inoculum concentration also gave difference in the percentage of hydrocarbon component composition at the end of incubation time (Figure 5). Aliphatic components are degraded faster than aromatic and polyaromatic components. The accumulation of aromatic compounds in culture with the addition of $10 \%$ and $15 \%$ is a bit of bacterial growth inhibitor.

The use of bioslurry reactors is considered effective when used in biodegradation of organic compounds such as hydrocarbons. This is evidenced by a short time of 14 days that can degrade oil sludge by $55.06 \%$ (initial TPH $30 \%$ ). Cassidy (2001), states that the weakness possessed by the bioslurry reactor in the process of biodegradation of hydrocarbon compounds is the formation of unpredictable foams. The production of this foam can occur rapidly during the stirring process especially when the speed of stirring and aeration are quite high.

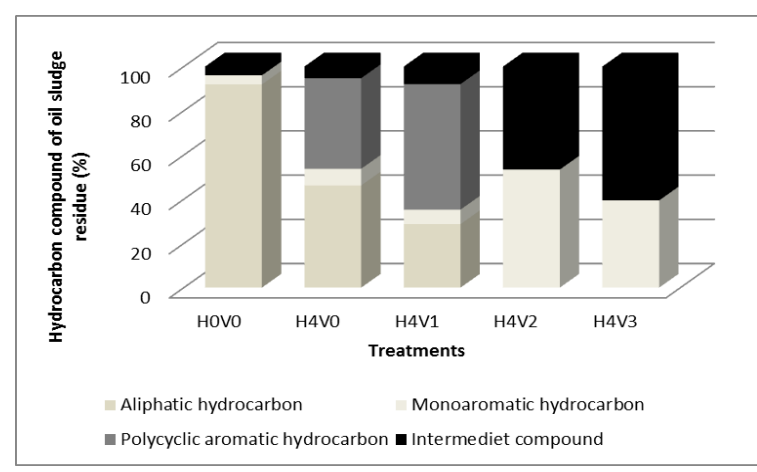

Figure 5: The remaining hydrocarbon components in all treatments at 14 days of incubation. HOVO is control of treatments in 0 day incubation, $\mathrm{H} 4 \mathrm{VO}$ is control of treatments in 14 days incubation, H4V1 is concentration of bacterial consortium of $5 \%(\mathrm{v} / \mathrm{v})$ in 14 days incubation, H4V2 is concentration of bacterial consortium of $10 \%$ $(\mathrm{v} / \mathrm{v})$ in 14 days incubation, and H4V3 is concentration of bacterial consortium of $15 \%(\mathrm{v} / \mathrm{v})$ in 14 days incubation

Two percent of molasses can be used as biostimulant in the biodegradation of oil sludge hydrocarbons. Determination of minimum level of nutrients in molasses that was needed for metabolism of hydrocarbon degrading bacteria becomes research targets that has prospective to be developed for efficient waste treatment. The use of molasses in the handling or treatment of hydrocarbon waste can also support the utilization of organic waste in the environment.

\section{CONCLUSION}

Variations in the concentration of microbial consortium and length of incubation time using bioslurry reactor have an effect on total microbial number $(\mathrm{CFU} / \mathrm{mL})$ and weight loss of oil sludge residue $(\mathrm{g} / \mathrm{g})$. The best combination was found in the H4V3 treatment (15\% of consortium, 14 days incubation) with a mean log value of total microbial cells of $21.77 \pm 1.22 \mathrm{CFU} / \mathrm{mL}$ and the mean percentage of oil sludge biodegradation of $78.04 \%$. The combination of biostimulation, bioaugmentation and bioventing methods using bioslurry reactor is highly prospective to be used in the processing of oil sludge.

\section{ACKNOWLEDGEMENTS}

The researchers would like to thank the Ministry of Research, Technology and Higher Education, Republic of Indonesia (Kemenristek Dikti) for funding the research through the National Strategic Research grant scheme in 2017. 


\section{REFERENCES}

Atlas, R. M. (1981). Microbial degradation of petroleum hydrocarbon: an environmental perspective. Microbial Review 45(1), 180-209.

Atlas, R. M. and Bartha, R. (1998). Microbial Ecology: Fundamentals and Aplication. Company Inc Publishing, California. pp. 300-338.

Charlena. (2010). Bioremediasi tanah tercemar limbah minyak berat menggunakan konsorsium bakteri. Thesis. Institut Pertanian Bogor, Indonesia.

Cassidy, D. P. (2001). Biological surfactan production in a biological slurry reactor treating diesel fuel contaminated soil. Water Environment Research 73(1), 87-94.

Cerqueira, V. S., Hollenbach, E. B., Maboni, F., Vainstein, M. H., Camargo, F. A.O., Peralba, M. C. R. and Bento, F. M. (2011). Biodegradation potential of oily sludge by pure and mixed bacterial cultures. Bioresource Technology 102, 11003-11010.

Gonzalez, I. V. R., Fava, F. and Varaldo, H. M. P. (2008). A review on slurry bioreactors for bioremediation of soils and sediments. Journal of Microbial Cell Factories 7(5), 1-16.

Goswami, P. and Singh, H. D. (1990). Different modes of hydrocarbon uptake by two Pseudomonas $\mathrm{sp}$. Biotechnology and Bioengineering 37, 1-11.

Karigar, C. and Rao, S., (2011). Role of microbial enzymes in the bioremediation of pollutants: A review. Enzyme Research Article ID 805187, 1-11.

Kriipsalu, M., Marques, M. and Maastik, A., (2008). Characterization of oily sludge from a wastewater treatment plant flocculation-flotation unit in a petroleum refinery and its treatment implications. Journal of Material Cycles and Waste Management 10 (1), 79-86.

Leahy, J. G. and Collwell, R. R. (1990). Microbial degradation of hydrocarbons in the environments. Microbial Reviews 54(3), 305-315.

Liu, J., Liu, G., Zhang, J., Yin, H. and Wang, R. (2012). Occurence and risk assessement of polycyclic aromatic hydrocarbon in soil from the Tiefa coal mine district, Liaoning, China. Journal of Environmental Monitoring 14(10), 2634-2642.

Mansur, A. A., Adetutu, E. M., Makadia, T., Morrison, P. D. and Ball, A. S. (2015). Assessment of the hydrocarbon degrading abilities of three bioaugmentation agents for the bioremediation of crude oil tank bottom sludge contaminated Libyan soil. International Journal of Environmental Bioremediation and Biodegradation 3(1), 1-9.

Ni'matuzahroh, Puspitasari, A. O., Pratiwi, I. A., Fatimah, Sumarsih, S., Surtiningsih, T. and Salamun. (2016a). Oil removal from petroleum sludge using bacterial culture with molasses substrate at temperature variation. In: AIP Conference Proceedings. American Institute of Physics. Maryland, Amerika. pp. 030002-1 - 030002-7.

Ni'matuzahroh, Fatimah, Sumarsih, S. and Yuliani, $H$. (2016b). Utilization of bacterial formula "biocleanoil" for oil tank cleaning and oil sludge treatment (in Indonesia). Research Report. Universitas Airlangga, Indonesia.

Ni'matuzahroh., Nurmalasari, R., Silvia, R. A., Nurhariyati, T. and Surtiningsih, T. (2015). Effectiveness in enhancing oil recovery through combination of biosurfactant and lipase bacteria. Journal of Applied Environmental and Biological Sciences 5(6), 83-87.

Ni'matuzahroh, Pratiwi, I. A., Surtiningsih, T., Fatimah. and Sumarsih, S. (2017). The potency of Micrococcus sp., LII 61 bacteria as oil sludge cleaning agent. Journal of Biological Researches 22(2), 38-42.

Panda, S., Kar, N. and Panda, R. (2013). Isolation and identification of petroleum hydrocarbon degrading microorganism from oil contaminated environment. International Journal of Environmental Sciences 3(5), 1314-1321.

Sari, G. L., Trihadiningrum, T. and Ni'matuzahroh. (2018). Petroleum hydrocarbon pollution in soil and surface water by public oil fields in wonocolo subdistrict, Indonesia. Journal of Ecological Engineering 1(2), 184-193.

Silvia, S. (2010). Biodegradation of petroleum hydrocarbon using bacterial isolate from crude oil waste. PT. Cevron Pasific Indonesia (in Indonesia). Thesis. Universitas Andalas, Indonesia.

Sumarsih, S., Ni'matuzahroh., Fatimah., Puspitasari, M. and Rusdiana, M., (2017). Effect of aliphatic and aromatic hydrocarbons on the oxygenase production from hydrocarbonoclactic bacteria. Journal of Chemical Technology and Methallurgy 52(6), 10621069.

United States Environmental Protection Agency (USEPA). (1990). Slurry Biodegradation. Engineering Bulletin, Washington D.C.

United States Environmental Protection Agency (USEPA). (1994). Method 1664: N-Hexane Extractable Material (HEM) and Silica Gel Treated NHexane Extractable Material (SGT-HEM) by Extraction and Gravimetry (Oil and Grease and Total Petroleum Hydrocarbons). Washington D.C.

United States Environmental Protection Agency (USEPA). (2009). Soil Hazard Categorization and Management, Industrial Waste Resource Guidelines. Washington D.C.

Wang, Q., Zhang, S., Li, Y. and Klassen, W. (2011). Potential approaches to improving biodegradation of hydrocarbons for bioremediation of crude oil pollution. Journal of Environmental Protection 2, 47-55.

Zhu, X., Venosa, A. D., Suidan, M. T. and Lee, K. (2001). Guidelines for the bioremediation of marine Shorelines and Freshwater Wetlands. In: Factors Affecting Natural Oil Biodegradation and Bioremediation Success. United States Environmental Protection Agency, Cincinnati, Ohio. pp. 9-43. 